\title{
FOREWORD
}

For many years the Knights of St. John have maintained a charitable hospital in Jerusalem. In more recent times this has been an Eye Hospital which currently cares for the eyes of patients from the West Bank and Gaza strip. This year is the 875th anniversary of the establishment of this hospital and this issue contains several articles which have resulted from the work of the hospital, together with an introduction by Sir Stephen Miller who is the Hospitaller of the Order. Sir Stewart Duke-Elder who was responsible for rebuilding the hospital on its present site, was not only hospitaller to the Order, but also President of both the Faculty of Ophthalmologists and the Ophthalmological Society of the United Kingdom from which our present College has arisen. The College of Ophthalmologists continues to have close associations with the hospital and wishes it well in the continuation of its excellent and essential work.

P. G. Watson

\section{The Knights of St John}

\author{
SIR STEPHEN MILLER K.C.V.O.
}

London

It is impossible to discuss the Order of the Hospital of St. John of Jerusalem without touching on the Crusades which were central to its origin. At the end of the 11 th century in the era of the first Crusade, life for the average individual in Europe was tough-going, violent, manifestly unfair and insecure. A strong and widespread belief that there was an omnipotent and merciful God in his Heaven gave a meaning to human existence which was otherwise not obvious to the average individual. The procuring of salvation was thus a general obsession occupying everyone's mind and religious discussion was constantly on the lips of people of all classes. A gateway was provided to this desirable attainment by the universal church's power to grant absolution of sins. With this background a lead from the church was likely to be accepted with enthusiasm.

In the first week of March 1095, Pope Urban II presided over a church council in northern Italy which was attended by an embassy from the Byzantine Emperor, Alexius and he asked for help against the Turks who had advanced across Asia Minor and were within striking distance of Constantinople. This advance presented a potent threat to Christianity from the world of Islam.

Pope Urban proceeded to summon the Bishops of France, in November of that year, to a council in Clermont and there he proclaimed, for the first time, the idea of a Crusade to liberate Jerusalem from the infidels.

The response in Europe to the proclamation of a Crusade was staggering and by the Spring of 1096 Peter the Hermit was the first to be on his way with a large following of Knights and plebs, the majority of whom were motivated by genuine idealism. In support of this view it must be borne in mind that a Knight was expected to bring with him the 